\title{
Environment Stratification in the Evaluation of Corn Hybrids in Southern Brazil
}

\author{
Maicon Nardino ${ }^{1}$, Diego Baretta ${ }^{1}$, Ivan Ricardo Carvalho ${ }^{1}$, Tiago Olivoto ${ }^{2}$, Diego Nicolau Follmann ${ }^{2}$, \\ Alan Junior de Pelegrin ${ }^{1}$, Vinícius Jardel Szareski ${ }^{1}$, Francine Lautenchleger ${ }^{3}$, Tiago Corazza da Rosa ${ }^{1}$, \\ Mauricio Horbach Barbosa ${ }^{1}$, Valmor Antonio Konflanz ${ }^{4}$, Willian Silva Barros ${ }^{1} \&$ Velci Queiróz de Souza \\ ${ }^{1}$ Federal University of Pelotas, Capão do Leão, RS, Brazil \\ ${ }^{2}$ Federal University of Santa Maria, Santa Maria, RS, Brazil \\ ${ }^{3}$ State University of Londrina, Department of Plant Science, Londrina, PR, Brazil \\ ${ }^{4}$ KSP Sementes, Brazil \\ ${ }^{5}$ Federal University of Pampa, São Gabriel, RS, Brazil \\ Correspondence: Ivan Ricardo Carvalho, Federal University of Pelotas, Capão do Leão, RS, Brazil. Tel: \\ 55-99-640-8757. E-mail: carvalho.irc@gmail.com
}

Received: October 13, 2017

doi:10.5539/jas.v10n10p333
Accepted: December 5, 2017 Online Published: September 15, 2018

URL: https://doi.org/10.5539/jas.v10n10p333

\begin{abstract}
The implementation of a network of maize trials is an onerous task, so breeding programs seek to eliminate redundant environments, remaining only contrasting ones. The objective was to perform the homogeneous environment grouping by studying the $\mathrm{G} \times \mathrm{E}$ interaction through different environmental stratification methods, as well as to compare the efficiency of these methods. Four methods were used: environmental dissimilarity $\left(\mathrm{D}_{\mathrm{jj}}\right)$; Decomposition of the genotype $\times$ environment interaction $(\mathrm{G} \times \mathrm{E})$ into simple and complex parts by Cruz and Castoldi; Pearson correlation coefficient; and factor analysis. Twenty-five single-cross corn hybrids and three commercial cultivars were tested in eight cultivation environments in a randomized complete block design with three replicates in the evaluation of grain yield. Quedas do Iguaçu and Cascavel can be reduced into only one test environment by methods of factor analysis and Pearson correlation. The environments of Pato Branco and Ampére are grouped by two of the four methods employed. However, Clevelândia, Londrina, and Coxilha do not group with other environments in three of the four methods, and Itapiranga in two of the four methods. Cruz and Castoldi's method and stratification by factor analysis are more rigorous in grouping criteria.
\end{abstract}

Keywords: Zea mays L., stratification methods, genotype $\times$ environment interaction, grain yield

\section{Introduction}

Corn, due to its nutritional value, adaptation to different edaphoclimatic conditions and high yields achievable, is one of the most cultivated cereals in the world, showing great social and economic importance. It is also worth noting the great increase in the employment of labor in the rural and urban areas, due to its participation as raw material for more than 500 industrial segments and highlighting the production chain of biofuels (Duete et al., 2009; Carvalho et al., 2015). Brazil stands out as one of the world's largest corn producers, surpassed only by the United States and China (Faostat, 2014). According to a Conab survey, the crop 2013/2014, Brazilian corn production was 78.96 million tons in 15.49 million hectares, with an average yield of 5,095 kg ha ${ }^{-1}$ (Conab, 2014). However, the national average of corn yields is much lower than desired, considering that its productive potential, employing high technological levels, exceeds 16,000 $\mathrm{kg} \mathrm{ha}^{-1}$ (Duete et al., 2009; Carvalho et al., 2016; Nardino et al., 2016; Rosa et al., 2018).

The cultivated plants are submitted to the most different cultivation conditions. These variations may be due to soil fertility, temperature, precipitation, rainfall among other factors. Under these conditions, the behavior of the genotypes is not expected to be consistent in the different environments that are evaluated, that is, expected the occurrence of strong genotype $\times$ environment $(\mathrm{G} \times \mathrm{E})$ interaction (Szareski et al., 2016). Thus, breeders are required to evaluate their cultivars and/or lineages in experiments conducted at various locations and/or agricultural crops (Ramalho et al., 2012). 
The evaluation of the $\mathrm{G} \times \mathrm{E}$ interaction becomes of great importance in plant breeding, because when present, it influences the selection gain and hinders the correct recommendation of cultivars with wide adaptability (Szareski et al., 2017; Nardino et al., 2017). Due to the importance of this interaction, it is in the interest of the breeder to evaluate its magnitude and significance, quantify its effects on breeding techniques and strategies for diffusion of technologies, providing subsidies that allow strategies to be minimized and/or exploited (Cruz et al., 2012).

Implementing a test network is a costly and expensive task. One of the major concerns of breeding programs is that the environments in which their genotypes are submitted are representative of the diversity of environments where their hybrids are grown and whether these environments provide additional information. As a way to reduce costs in breeding programs, it is necessary to eliminate redundant environments, remaining only the contrasting environments (Pereira et al., 2010; Demari et al., 2016; Zimmer et al., 2017). Therefore, it is fundamental to identify among the available environments, those that reveal similarity patterns regarding the genotype response, in such a way that it allows to evaluate the degree of representativeness of the assays of the crop adaptation range. Thus, we have the possibility of making decisions about the disposal of environments when there are technical problems or resource scarcity, and identify groups of environments in which the interaction may not be significant for the set of available genotypes (Cruz et al., 2012). There are several studies in the literature that address methods of environmental stratification carried out on maize (Ribeiro \& Almeida, 2011; Felipe et al., 2010; Garbuglio et al., 2007; Silva et al., 2004).

In this context, the objective of this work was to group homogeneous environments through the study of the $\mathrm{G} \times \mathrm{E}$ interaction through different methods of environmental stratification, as well as to compare the efficiency of these methods through the response of 28 single-cross corn hybrids in eight environments in the States of Paraná, Santa Catarina and Rio Grande do Sul.

\section{Material and Methods}

The VCU's trials were conducted in eight environments, six in the State of Paraná, one in Santa Catarina and one in Rio Grande do Sul in the 2011/2012 crop, as described in Table 1. The germplasm used came from the company KSP Seeds Ltda., with its head office in the municipality of Pato Branco-PR. The environments adopted in the evaluation of the hybrids are part of the network of tests used by the genetic breeding program of the company KSP Seeds Ltda.

There were used 28 single-cross pre-commercial hybrids resulting from the crossing of homozygous lineages belonging to the breeding company and three commercial hybrids used as untreated controls: P30F53, DKB240 and SG6303, totaling 28 tested materials.

A randomized complete block design was used, with three replications for all environments. The experimental units were composed of two rows of five meters, spaced 0.70 meters apart. The sowing time was performed according to the agroclimatic zoning for each environment. Soil management and cultural practices were the same for the eight environments, obeying the phenological stages and the need of the crop, where after the emergence and establishment of the culture the manual thinning was performed to adjust the stand of 42 plants per experimental unit, equivalent to $60,000 \mathrm{ha}^{-1}$ plants. Grain yield data were corrected for moisture content of $13 \%$ and adjusted for mass in $\mathrm{kg}$ per plot of each hybrid in the eight environments.

The data were submitted to analysis of individual variance by environment and joint, being considered the fixed effect genotypes, the environments as random effect and the interaction $\mathrm{G} \times \mathrm{E}$ as random effects. In the analysis of joint variance, it was verified that the ratio between the largest and the smallest mean square of the residue was a magnitude lower than seven, indicating that the residual variances were homogeneous (Cruz et al., 2012).

The environments were stratified using four methods, with the aid of the Genes computational program (Cruz, 2013), being: methods of the squared Euclidean average distance based on the interaction $G \times E\left(D_{j j}\right)$; Cruz and Castoldi's (1991) method (percentage associated with the simple and complex part of the interaction); Pearson correlation estimates; and factor analysis (Murakami \& Cruz, 2004).

In the dissimilarity method between environments, the squared Euclidean average distance, based on the $\mathrm{G} \times \mathrm{E}$ interaction $\left(\mathrm{D}_{\mathrm{jj}}\right)$ was used as measure, and, through the distances, the grouping was performed by the Tocher optimization method. Cruz and Castoldi (1991) method consists of quantifying the $\mathrm{G} \times \mathrm{E}$ interaction among pairs of environments in a simple and complex part. It was obtained the portion of the complex part of the interaction, which is generated by the low correlation between the environments, due to the irregular behavior of the genotypes (Cruz et al., 2012). The correlation magnitudes below 0.5 were considered as similar environments. The Pearson correlation method was estimated between the averages of the genotypes in the pairs of 
environments, being considered as similar when evidenced magnitudes of correlations between the environment pairs.

In the stratification of environments based on factor analysis (Murakami \& Cruz, 2004), the grouping is carried out from the information about the magnitude of the factorial loads, obtained after rotation, being: factorial loads greater or equal to 0.70 , in absolute value, indicate environments with high correlation; factorial loads with values below 0.50 indicate that the environments should not belong to the same group; and factorial loads with intermediate values do not guarantee any grouping definition. The number of final factors, considered in the stratification, was considered a proportion in which up to $80 \%$ of the total variation was reached.

\section{Results and Discussion}

It was verified through the analysis of individual variance (Table 1$)$, a high significance $(p<0.01)$ by the $F$ test, indicating a differentiated response of the genotypes in the study environments. The values of the coefficients of variation (CVs) ranged from 5.10\% for Clevelândia and 13.95\% for Quedas do Iguaçu, with an average of 9.90\%, indicating good experimental precision according to the scale proposed by Scapim et al. (1995). The average grain yield in the plot (GY) was between $10.69 \mathrm{~kg}$ for Clevelândia and $5.39 \mathrm{~kg}$ for Londrina, with a general average of $8.09 \mathrm{~kg}$, revealing great variation in the conditions under which the tests were conducted. This fact can be attributed, in part, to the geographic heterogeneity of the analyzed environments, with altitudes ranging from 190 to $960 \mathrm{~m}$, latitude $23^{\circ} 19^{\prime} 39^{\prime \prime}$ to $28^{\circ} 07^{\prime} 38^{\prime \prime} \mathrm{S}$, and longitude of $51^{\circ} 07^{\prime} 47^{\prime \prime}$ to $53^{\circ} 42^{\prime} 07^{\prime \prime} \mathrm{W}$, respectively, it certainly reveals climatic differences among the environments used for the tests, due to the differences among the environments, when verifying the values of the mean square residue (MSR), it can be verified that the relation among the higher and lower values of this parameter, was equal to 4.43. According to Cruz et al. (2012) a ratio less than seven indicates that there is homogeneity of the residual variances obtained in the analysis, allowing the joint analysis of the sites to be performed without restrictions.

Table 1. Geographic characterization of the environments and summary of the analyzes of individual variances of eight environments, related to the grain yield character

\begin{tabular}{llllllll}
\hline Environment & Altitude $(\mathrm{m})$ & Latitude & Longitude & \multicolumn{2}{c}{ Mean Square } \\
& & & & Genotypes & Residue $^{(1)^{--}}$ & $\mathrm{GY}^{(3)}(\mathrm{kg})$ & $\mathrm{CV}^{(2)}(\%)$ \\
\hline Clevelândia-PR & 960 & $26^{\circ} 24^{\prime} 17^{\prime \prime} \mathrm{S}$ & $52^{\circ} 21^{\prime} 04^{\prime \prime} \mathrm{W}$ & $2,354^{* *}$ & 0.297 & 10.69 & 5.10 \\
Coxilha-RS & 710 & $28^{\circ} 07^{\prime} 38^{\prime \prime} \mathrm{S}$ & $52^{\circ} 17^{\prime} 41^{\prime \prime} \mathrm{W}$ & $2,207^{* *}$ & 0.833 & 6.54 & 13.95 \\
Pato Branco-PR & 760 & $26^{\circ} 13^{\prime} 46^{\prime \prime} \mathrm{S}$ & $52^{\circ} 40^{\prime} 15^{\prime \prime} \mathrm{W}$ & $3,448^{* *}$ & 0.735 & 9.02 & 9.50 \\
Quedas do Iguaçu-PR & 580 & $25^{\circ} 27^{\prime} 00^{\prime \prime} \mathrm{S}$ & $52^{\circ} 54^{\prime} 37^{\prime \prime} \mathrm{W}$ & $7,903^{* *}$ & 1.041 & 10.12 & 10.08 \\
Itapiranga-SC & 190 & $27^{\circ} 10^{\prime} 19^{\prime \prime} \mathrm{S}$ & $53^{\circ} 42^{\prime} 07^{\prime \prime} \mathrm{W}$ & $2,171^{* *}$ & 0.493 & 7.88 & 8.91 \\
Londrina-PR & 560 & $23^{\circ} 19^{\prime} 39^{\prime \prime} \mathrm{S}$ & $51^{\circ} 07^{\prime} 47^{\prime \prime} \mathrm{W}$ & $4,898^{* *}$ & 0.235 & 5.39 & 8.98 \\
Cascavel-PR & 785 & $24^{\circ} 58^{\prime} 03^{\prime \prime} \mathrm{S}$ & $53^{\circ} 24^{\prime} 51^{\prime \prime} \mathrm{W}$ & $5,453^{* *}$ & 0.458 & 7.46 & 9.07 \\
Ampére-PR & 495 & $25^{\circ} 55^{\prime} 02^{\prime \prime} \mathrm{S}$ & $53^{\circ} 28^{\prime} 08^{\prime \prime} \mathrm{W}$ & $2,448^{* *}$ & 0.293 & 7.60 & 7.11 \\
Average & - & - & - & - & - & 8.09 & 9.90 \\
\hline
\end{tabular}

Note. ${ }^{(1)}$ The ratio between largest and smallest mean square of the residue was $4.43 ;{ }^{\text {ns }}$ Not significant; $*$ and ${ }^{* *}$ Significant at 5 and $1 \%$ of probability, respectively, by the $\mathrm{F}$ test; ${ }^{(2)} \mathrm{CV}=$ Coefficient of variation; ${ }^{(3)} \mathrm{GY}=\mathrm{Grain}$ yield.

From the joint analysis (Table 2) it was revealed that the source of genotype variation was significant $(\mathrm{p}<0.01)$ for the set of environments studied, thus evidencing the existence of genetic variability among the analyzed hybrids. High significance was also revealed for the source of environmental variation, where it can be inferred that the set under study was composed of different environments. For the source of variation $G \times E$, a significant effect $(p<0.01)$ was observed, indicating a differentiated response of the genotypes in each environment, and that there are changes in the magnitude of the GY response by varying the environments, thus justifying the analysis of environmental stratification. According to Silva et al. (2008) the occurrence of distinction among environments and genotypes is a favorable condition for the interaction to manifest. 
Table 2. Summary of the analysis of the combined variance for 28 hybrids of corn, in eight environments, regarding the grain yield character

\begin{tabular}{lll}
\hline Sourceofvariation & DF & Mean Square \\
\hline Block & 2 & 5.39 \\
Genotype (G) & 27 & $10.06^{* *}$ \\
Environment (E) & 7 & $265.39^{* *}$ \\
$\mathrm{G} \times \mathrm{E}$ & 189 & $2.97 * *$ \\
Residue & 446 & 0.64 \\
\hline Average & - & 8.09 \\
$\mathrm{CV}(\%)$ & - & 9.90 \\
\hline
\end{tabular}

Note. ${ }^{\text {ns }}$ Not significant; $*$ and ${ }^{* *}$ Significant at 5 and $1 \%$ of probability, respectively, by the $\mathrm{F}$ test; $\mathrm{DF}=$ Degrees of freedom; $\mathrm{CV}=$ Coefficient of variation.

In Table 3, the measure of dissimilarity among environments is shown by the Euclidean average distance method based on the interaction $G \times E\left(D_{\mathrm{jj}}\right)$. The Ampére environment, on average, revealed the lowest distance estimate among all pairs of environments, with a magnitude of 1.489 , the lowest values of $\mathrm{D}_{\mathrm{jj}}$ observed among the environment pairs were between Pato Branco and Ampére $(1,012)$. On the other hand, Londrina environment had the highest average distance among the pairs of environments, highlighting Quedas do Iguaçu and Londrina $(3,982)$, with the highest number of $\mathrm{D}_{\mathrm{jj}}$. For Cruz (2006) the evaluation of the pattern of similarities and/or dissimilarities measures of different environments, as to their ability to discriminate genotypes, has been of great relevance in breeding programs, since it quantifies the degree of representativity of the experimental network.

Table 3. Estimates of the Euclidean average distance based on the $G \times E$ interaction $\left(D_{j j}\right)$ for 28 single-cross corn hybrids evaluated in 8 growing environments

\begin{tabular}{|c|c|c|c|c|c|c|c|c|c|}
\hline Environments ${ }^{(I)}$ & E1 & E2 & E3 & E4 & E5 & E6 & E7 & E8 & $\mathrm{D}_{\mathrm{jj}}$ Average \\
\hline E1 & - & 1.471 & 1.551 & 3.112 & 1.266 & 2.250 & 2.218 & 1.399 & 1.895 \\
\hline E2 & & - & 1.444 & 2.707 & 1.522 & 2.078 & 1.671 & 1.131 & 1.718 \\
\hline E3 & & & - & 1.826 & 1.317 & 2.911 & 1.746 & 1.012 & 1.687 \\
\hline E4 & & & & - & 2.349 & 3.982 & 1.448 & 2.117 & 2.506 \\
\hline E5 & & & & & - & 1.467 & 1.637 & 1.277 & 1.548 \\
\hline E6 & & & & & & - & 3.146 & 1.753 & 2.512 \\
\hline E7 & & & & & & & - & 1.734 & 1.943 \\
\hline E8 & & & & & & & & - & 1.489 \\
\hline
\end{tabular}

Note. ${ }^{(1)}$ E1 = Clevelândia, E2 = Coxilha, E3 = Pato Branco, E4 = Quedas do Iguaçu, E5 = Itapiranga, E6 = Londrina, $\mathrm{E} 7=$ Cascavel and E8 $=$ Ampére.

Concerning the clustering based on the Tocher optimization method, it can be observed in Table 4, the partition of the eight environments analyzed in three groups. Group I was formed by PatoBranco, Ampére, Coxilha, Clevelândia and Itapiranga, which stood out because it revealed the greatest number of environments, indicating a proportion of $62.5 \%$ of the total environments contained in this group. The higher values of latitude coordinates, revealed by the environments that composed this group, with amplitudes from $25^{\circ}$ to $28^{\circ} \mathrm{S}$, may have favored the achievement of this result. However, there was discrepancy regarding the geographic location of these environments in terms of altitude, revealing environments with low and high indexes. This divergence was also obtained by Ribeiro and Almeida (2011), and Uitzil et al. (2016) showing that a possible justification, for clusters of environments with such oscillations, would be compatible with similar conditions of thermal amplitude and water availability, during the sowing period to flowering, referring to this subset of environments. 
Table 4. Clustering of eight environments by the Tocher optimization method based on the Euclidean average distance based on the $\mathrm{G} \times \mathrm{E}$ interaction $\left(\mathrm{D}_{\mathrm{jj}}\right)$, considering the grain yield character

\begin{tabular}{ll}
\hline Groups & Environments $^{(1)}$ \\
\hline I & E3, E8, E2, E5, E1 \\
II & E4, E7 \\
III & E6
\end{tabular}

Note. ${ }^{(1)} \mathrm{E} 1=$ Clevelândia, E2 = Coxilha, E3 = Pato Branco, E4 = Quedas do Iguaçu, E5 = Itapiranga, E6 = Londrina, $\mathrm{E} 7=$ Cascavel and E8 $=$ Ampére.

Group II was formed by the environments Quedas do Iguaçu and Cascavel. Group III was formed only by Londrina environment, indicating that the environment was more distant and did not show a pattern of similarity with the others. Thus, it stands out as an important place to compose the network of competitive trials of pre-commercial cultivars. A similar result was obtained by Carvalho et al. (2002) analyzing a network of environments used to conduct competitive trials of early soybean lineages, where Londrina was the environment that did not reveal patterns of similarity with any other that composed the analyzed network.

Therefore, in subsequent evaluations, it is possible to consider only one of the environments belonging to each group formed, being the breeder's decision the choice of the environment that best fits the needs and desires of the breeding program. This reduction in the number of environments comprising the evaluation network of the cultivars, which have similarity patterns due to genotype responses, will reduce hybrids' evaluation costs, as well as allow more rigorous evaluations in the remaining trials (Cruz et al., 2012; Peluzio et al., 2012; Olivoto et al., 2016; Pelegrin et al., 2016; Ferrari et al., 2016/2018; Szareski et al., 2018). For Pacheco et al. (1998) the conduction of experiments in several environments and years, aiming to mitigate the effects of $G \times E$ interaction, demands the additional need of human and financial resources, in addition to a greater quantity of seeds. This limits the number of environments and years in which the experiments can be conducted, making it necessary to choose representative environments for which the hybrid will be adapted.

Robertson (1959) classified the $\mathrm{G} \times \mathrm{E}$ interaction into simple and complex. The first is provided by the difference of variation among genotypes in the environments, since the relative position of the genotypes is not altered. This type of interaction does not present great problems to the breeder, because genotypes that are superior in one environment will also be it in another one. The second one is due to the lack of correlation between the performances of the genotypes, revealing different responses to the variations of the environments, changing their classification, considering the different environments.

In the decomposition of the interaction, using the expression proposed by Cruz and Castoldi (1991) (Table 5), it was observed that the fraction due to the complex part represented, for the character GY, the totality of the G $\times E$ interaction, not being verified any fraction due to the simple part among the pairs of environments, with limits below 50\%. For Peluzio et al. (2012) this shows the inconsistency of the behavior of the genotypes with the variation of the environments. Quedas do Iguaçu and Cascavel environments were identified as similar because they showed a high correlation coefficient $\left(\mathrm{r}=0.674^{* *}\right)$, but the $57.797 \%$ of the complex interaction exceeded the limits of $50 \%$ in order to affirm that the interaction is of the simple type (Table 5). The significant correlation among Quedas do Iguaçu, Pato Branco $\left(\mathrm{r}=0.543^{*}\right)$ and Ampére $\left(\mathrm{r}=0.428^{*}\right)$ environments was also highlighted. 
Table 5. Estimates of the Pearson correlation coefficients among environments (upper diagonal) and percentage of complex fraction (lower diagonal) resulting from the $\mathrm{G} \times \mathrm{E}$ interaction, among pairs of evaluated environments of 28 single-cross hybrids of corn, regarding the grain yield character

\begin{tabular}{lllllllll}
\hline & E1 $^{(1)}$ & E2 & E3 & E4 & E5 & E6 & E7 & E8 \\
\hline E1 & - & $-0.003^{\text {ns }}$ & $0.171^{\text {ns }}$ & $0.067^{\text {ns }}$ & $0.130^{\text {ns }}$ & $0.037^{\text {ns }}$ & $0.126^{\text {ns }}$ & $0.093^{\text {ns }}$ \\
E2 & 100.095 & - & $0.211^{\text {ns }}$ & $0.202^{\text {ns }}$ & $-0.081^{\text {ns }}$ & $0.098^{\text {ns }}$ & $0.355^{\text {ns }}$ & $0.244^{\text {ns }}$ \\
E3 & 89.068 & 86.122 & - & $0.543^{*}$ & $0.278^{\text {ns }}$ & $-0.087^{\text {ns }}$ & $0.400^{*}$ & $0.473^{*}$ \\
E4 & 80.337 & 70.701 & 56.760 & - & $0.334^{\text {ns }}$ & $0.033^{\text {ns }}$ & $0.674^{* *}$ & $0.428^{*}$ \\
E5 & 93.180 & 103.971 & 81.903 & 61.642 & - & $0.384^{*}$ & $0.368^{\text {ns }}$ & $0.140^{\text {ns }}$ \\
E6 & 91.677 & 87.225 & 102.779 & 95.492 & 69.081 & - & $0.055^{\text {ns }}$ & $0.273^{\text {ns }}$ \\
E7 & 84.779 & 69.184 & 74.185 & 54.221 & 67.927 & 97.086 & - & $0.343^{\text {ns }}$ \\
E8 & 95.192 & 86.784 & 70.624 & 57.797 & 92.542 & 78.673 & 72.120 & -
\end{tabular}

Note. ${ }^{(1)}$ E1 = Clevelândia, E2 = Coxilha, E3 = Pato Branco, E4 = Quedas do Iguaçu, E5 = Itapiranga, E6 = Londrina, $\mathrm{E} 7=$ Cascavel and E8 $=$ Ampére. $*$ and $* *=$ significant correlation at 1 and $5 \%$ of probability by the $\mathrm{t}$ test, respectively; ${ }^{\mathrm{ns}}=$ not significant.

In the same way, Pato Branco environment showed good agreement with Cascavel and Ampére environments, revealing significant correlation coefficients, although of moderate magnitude $\left(\mathrm{r}=0.400^{*}\right.$ and $\left.\mathrm{r}=0.473 *\right)$, respectively, but not presenting in these pairs fraction of simple interaction. The same previous comment can also be made with pairs of environments of Itapiranga and Londrina $\left(r=0.384^{*}\right)$. The complex interaction represented, on average, $81.11 \%$ of the total variation, and the average correlation coefficient was 0.225 , which corroborates with the existence of large differences among the evaluated environments (Table5).

Pereira et al. (2010), working with 16 carioca beans genotypes in 25 environments in the state of Goiás and the Federal District, found $94 \%$ of pairs of environments with predominance of complex interaction, and $92 \%$ of pairs with low correlation. In soybean, analyzing 15 environments in the states of Paraná and Santa Catarina, Mendonça et al. (2007) found $\mathrm{G} \times \mathrm{E}$ interaction with predominance of complex part and coefficients of correlation with low magnitude in $90 \%$ among the environments. Garbuglio et al. (2007) in a study with 27 maize cultivars in 22 environments, found in $87 \%$ of pairs of environments $\mathrm{G} \times \mathrm{E}$ interactions with predominance of complex part and $56 \%$ with low magnitude of Pearson correlations. Pacheco et al. (2008) verified in ten environments, working with a diallel cross involving 28 open-pollinated maize populations, which was predominant in $100 \%$ of the interaction pairs of the complex part. Ribeiro and Almeida (2011), analyzing two sets of genotypes (sets 1 and 2) in ten environments in the states of Paraná, Minas Gerais and Bahia, revealed predominantly complex interactions in $96 \%$ and $100 \%$ pairs of environments, respectively.

In the technique of factors proposed by Murakami and Cruz (2004), it was verified that five eigenvalues explained $86.510 \%$ of the total variation (Table 6). The lowest value of cumunalities obtained was of 0.757 , revealing high efficiency in the representation of the variation by a common part. According to Cruz and Carneiro (2006), a cumulative value of more than 0.64 has been accepted, being this magnitude equivalent to having a correlation higher than 0.80 between the standardized variable $\left(\mathrm{x}_{\mathrm{j}}\right)$ and the common part $\left(\mathrm{z}_{\mathrm{j}}\right)$.

Table 6. Estimates of eigenvalues and environmental stratification by factor analysis for 28 single corn hybrids evaluated in eight growing environments

\begin{tabular}{|c|c|c|c|c|c|c|c|c|}
\hline \multirow{2}{*}{ Environment $^{(1)}$} & \multicolumn{2}{|c|}{ Estimatesofeigenvalues } & \multicolumn{5}{|c|}{ Factorloadsafterrotation } & \multirow{2}{*}{ Communality } \\
\hline & Root & $\%$ Accumulated & Factor 1 & Factor 2 & Factor 3 & Factor 4 & Factor 5 & \\
\hline E1 & 2.830 & 35.340 & 0.050 & 0.024 & 0.000 & 0.991 & 0.067 & 0.990 \\
\hline E2 & 1.290 & 51.440 & 0.157 & 0.043 & 0.935 & 0.000 & 0.110 & 0.912 \\
\hline E3 & 1.080 & 64.920 & 0.476 & -0.191 & -0.024 & 0.148 & 0.687 & 0.757 \\
\hline E4 & 0.940 & 76.630 & 0.778 & -0.055 & 0.085 & -0.038 & 0.405 & 0.782 \\
\hline E5 & 0.790 & 86.510 & 0.656 & 0.544 & -0.327 & 0.113 & -0.030 & 0.846 \\
\hline E6 & 0.520 & 93.050 & -0.023 & 0.950 & 0.088 & 0.003 & 0.100 & 0.921 \\
\hline E7 & 0.320 & 97.070 & 0.831 & 0.023 & 0.333 & 0.069 & 0.135 & 0.825 \\
\hline E8 & 0.230 & 100.000 & 0.108 & 0.251 & 0.167 & 0.010 & 0.886 & 0.887 \\
\hline
\end{tabular}

Note ${ }^{(1)}$ E1 = Clevelândia, E2 = Coxilha, E3 = Pato Branco, E4 = Quedas do Iguaçu, E5 = Itapiranga, E6 = Londrina, E7 $=$ Cascavel and E8 = Ampére. 
Factor 1 allowed the grouping of the environments of Quedas do Iguaçu and Cascavel, which revealed factorial loads greater than 0.70 . Itapiranga environment can not be safely included or excluded in this group because it presents factorial loads with intermediate values. Factor 2 grouped only Londrina environment, and it is not possible to include or exclude Itapiranga environment from the cluster. The Coxilha environment isolated the cluster according to factor 3. Factor 4 grouped the environment of Clevelândia. Factor 5 generated an isolated group formed by the Ampére environment, not allowing the inclusion or exclusion, safely, of the PatoBranco environment in this grouping. PatoBranco and Itapiranga environments were not grouped in any of the five factors, as they did not reach factorial loads above 0.70 .

Comparing the results obtained by all methods, it is possible to verify the association between the environments Falls of Iguaçu and Cascavel in the methods of dissimilarity among environments $\left(\mathrm{D}_{\mathrm{jj}}\right)$, Pearson's correlation and factor analysis, revealing the possibility of exclusion of one of these environments in analysis of the future test network. However, some caution is required because, according to Ribeiro and Almeida (2011), before the exclusion of a safe environment, it is preferable to have information of a greater number of crops. However, in the Cruz and Castoldi (1991) method, this pair of environments revealed predominance of a complex part in the $\mathrm{G} \times \mathrm{E}$ interaction.

Another interesting result concerns the environments of PatoBranco and Ampére that revealed similarity by Pearson correlation methods and dissimilarity between environments $\left(D_{\mathrm{ji}}\right)$, although the same previous comment can also be made, since it is consistent with the Cruz and Castoldi's (1991) method, with a predominance of a complex part in the $\mathrm{G} \times \mathrm{E}$ interaction and no grouping of these environments via stratification by factor analysis, since this method revealed formation of the cluster with Ampere environment, but not allowing the safe grouping of PatoBranco environment, for presenting a factorial load with intermediate values between 0.50 and 0.70 .

It is worth noting that the non-clustering of some environments, through the studied methods, reveals that these environments were essential for the evaluation of the hybrids set for the correct recommendation of the pre-commercial cultivars, namely: Clevelândia, Londrina and Coxilha, which did not cluster with other environments in three of the four methods and Itapiranga in two of the four methods. The method of Cruz \& Castoldi (1991) did not reveal an association with environments, and along with the method of stratification by factor analysis that grouped a smaller number of environments, they proved to be the most rigorous in the criteria of clustering, in disagreement with the methods of Pearson correlation and dissimilarity between environments $\left(\mathrm{D}_{\mathrm{jj}}\right)$.

The execution of environmental stratification analyzes is important for the maintenance or alteration of the evaluation network in an effective way. Ribeiro and Almeida (2011) analyzing several methodologies for environmental stratification revealed a moderate to strong association, indicating a good degree of similarity obtained by any of the methods, emphasizing the methods based on factor analysis and Cruz and Castoldi (1991), who proved to be more stringent in the process of environmental stratification. In the same way, Oliveira et al. (2005) verified that the method based on the factor analysis, showed to be more effective to show similarity among the environments in the environmental stratification, in beans trials analyzed in 14 environments.

\section{Conclusion}

There are differences among methods of environments stratification applied in this study.

Quedas do Iguaçu and Cascavel can be reduced to only one test environment by Pearson correlation and factor analysis methods.

The environments of Pato Branco and Ampére are grouped by two of the four methods employed. However, Clevelândia, Londrina, and Coxilha do not group with other environments in three of the four methods, and Itapiranga in two of the four methods, being fundamental in the evaluation of pre-commercial hybrids.

The methods of Cruz and Castoldi (1991) and stratification by factor analysis are more rigorous in the clustering criteria than the methods of Pearson correlation coefficient and dissimilarity among environments $\left(D_{j j}\right)$.

\section{References}

Carvalho, C. G. P., Arias, C. A. A., Toledo, J. F. F., Almeida, L. A., Souza Kiihl, R. A., \& Oliveira, M. F. (2002). Genotype $\times$ environment interaction on saybean yielding in Paraná State. Brazilian Journal of Agricultural Research, 37(7), 989-1000. Retrieved from http://www.scielo.br/pdf/pab/v37n7/10803

Carvalho, I. R., Korcelski, C., Peruzzo, S. T., Follmann, D. N., Nardino, M., Souza, V. Q., ... Caron, B. O. (2015). Physiological effects attributed to the cold test and addition of plant regulators in corn hybrids. Scientia Plena, 11(3), 030201. Retrieved from https://www.scientiaplena.org.br/sp/article/view/1953 
Carvalho, I. R., Nardino, M., Pelegrin, A. J., Ferrari, M., Demari, G., Szareski, V. J., ... Souza, V. Q. (2016). Path analysis and Annicchiarico method applied in relation to protein in corn grains. Australian Journal of Basic and Applied Sciences, 10, 300-306.

CONAB. (2014). Retrieved March 1, 2014, from http://www.conab.gov.br

Cruz, C. D. (2013). GENES-A software package for analysis in experimental statistics and quantitative genetics. Acta Scientiarum, 35(3), 271-276. https://doi.org/10.4025/actasciagron

Cruz, C. D., \& Carneiro, P. C. S. (2006). Modelos biométricos aplicados ao melhoramento genético (2nd ed.). Viçosa, MG-BR: UFV Press.

Cruz, C. D., \& Castoldi, F. (1991). Decomposição da interação genótipos $\times$ ambientes em partes simples e complexas. Revista Ceres, 38, 422-430. Retrieved from http:/www.ceres.ufv.br/ojs/index.php/ceres/article/ view/2165/203

Cruz, C. D., Regazzi, A. J., \& Carneiro, P. C. S. (2012). Modelos biométricos aplicados ao melhoramento genético. Viçosa, MG-BR: UFV Press.

Demari, G., Carvalho, I. R., Nardino, M., Szareski, V. J., Dellagostin, S. M., Rosa, T. C., ... Souza, V. Q. (2016). Importance of Nitrogen in Maize Production. International Journal of Current Research, 8, 6629-36634. Retrieved from http:/www.journalcra.com/sites/default/files/15932.pdf

Duete, R. R. C., Muraoka, T., Silva, E. C., Trevelin, P. C. O., \& Ambrosano, E. J. (2009). Economic viability of doses and split-applications of nitrogen fertilization in corn crop in a eutrophic Red Latosol. Acta Scientiarum Agronomy, 31, 175-181. https://doi.org/10.4025/actasciagron.v31i1.6646

FAOSTAT. (2014). Retrieved March 1, 2014 from http://faostat.fao.org

Felipe, R. D. P., Duarte, J. B., \& Camarano, L. F. (2010). Environmental stratification for maize varieties evaluation and recommendation in goiás state, Brazil. Pesquisa Agropecuária Tropical, 40(2), 186-199. Retrieved from https://www.revistas.ufg.br/index.php?journal=pat\&page=article\&op=view\&path $\% 5 \mathrm{~B} \% 5 \mathrm{D}$ $=6158 \&$ path $\% 5 B \% 5 \mathrm{D}=6890$

Ferrari, M., Pelegrin, A. J., Carvalho, I. R., Nardino, M., Szareski, V. J., ... Souza, V. Q. (2018). Path analysis and phenotypic correlation among yield components of soybean using environmental stratification methods. Australian Journal of Crop Science, 12(2), 193-202. https://doi.org/10.21475/ajcs.18.12.02.pne488

Ferrari, M., Pelegrin, A. J., Nardino, M., Carvalho, I. R., Szareski, V. J., Olivoto, T., ... Souza, V. Q. (2016). Evaluation of soybeans genotypes in field environments of Rio Grande do Sul state, Brazil. International Journal of Current Research, 8(9), 38383-38392.

Garbuglio, D. D., Gerage, A. C., Araújo, P. D., Fonseca Junior, N. D. S., \& Shioga, P. S. (2007). Factor analysis and bissegmented regression for studies about environmental stratification and maize adaptability. Brazilian Journal of Agricultural Research, 42(2), 183-191. https://doi.org/10.1590/S0100-204X2007000200006

Murakami, D. M., \& Cruz, C. D. (2004). Proposal of methodologies for environment stratification and analysis of genotype adaptability. Crop Breeding and Applied Biotechnology, 4, 7-11. https://doi.org/10.12702/ 1984-7033.v04n01a02

Nardino, M., Baretta, D., Carvalho, I. R., Ferrari, M., Pelegrin, A. J., Szareski, V. J., ... Souza, V. Q. (2017). Genetic divergence among corn (Zea mays L.) genotypes in distinct environments. Revista de Ciências Agrárias, 40(1), 164-174. https://doi.org/10.19084/RCA16013

Nardino, M., Baretta, D., Follmann, D. N., Carvalho, I. R., Olivoto, T., Szareski, V. J., ... Souza, V. Q. (2016). Genetic parameters in maize hybrids analysis in different environments. International Journal of Current Research, 8, 35552-35556. Retrieved from http://www.journalcra.com/sites/default/files/15689.pdf

Oliveira, G. V., Carneiro, P. D. S., Dias, L. D. S., Carneiro, J. D. S., \& Cruz, C. D. (2005). Factor analysis in the environment stratification for the evaluation of common bean cultivars. Crop Breeding and Applied Biotechnology, 5(2), 166-173. https://doi.org/10.12702/1984-7033.v05n02a06

Olivoto, T., Nardino, M., Carvalho, I. R., Follmann, D. N., Szareski, V. J., Ferrari, M., ... Souza, V. Q. (2016) Pearson Correlation Coefficients And Accuracy of Path Analysis Used in Maize Breeding: A Critical Review. International Journal of Current Research, 8, 37787-37795. Retrieved from http://www.journalcra. com/sites/default/files/17397.pdf 
Pacheco, C. A. P., Ramalho, M. A. P., \& Magnavaca, R. (1998). Genotypes $\times$ environment interaction in maize half-sib progenies evaluation. Brazilian Journal of Agricultural Research, 33(4), 433-439. Retrieved from https://seer.sct.embrapa.br/index.php/pab/article/viewFile/4861/6994

Pacheco, C. A. P., Silva, H. D., Santos, M. X., Oliveira Guimarães, P. E., Parentoni, S. N., Gomes, E., ... Junior, P. A. V. (2008). Environmental stratification based on a $28 \times 28$ diallel of open-pollinated maize varieties. Crop Breeding and Apllied Biotechnology, 8, 259-264. https://doi.org/10.12702/1984-7033.v08n04a01

Pelegrin, A. J., Carvalho, I. R., Nardino, M., Rigatti, A., Szareski, V. J., Ferrari, M., ... Maia, L. C. (2016). Traits of Importance for Corn Silage Production. International Journal of Current Research, 8, 38359-38369. Retrieved from http://www.journalcra.com/sites/default/files/16785.pdf

Peluzio, M. J., Gerominni, G. D. D., Silva, J. P. A., Afférri, F. S., \& Vendruscolo, J. B. G. (2012). Stratification and environmental dissimilarity for evaluation of soybean cultivars in the state of Tocantins. Bioscience Journal, 28(3), 332-337. Retrieved from http://www.seer.ufu.br/index.php/biosciencejournal/article/ view/9149

Pereira, H. S., Melo, L. C., Faria, L. D., Del Peloso, M. J., Díaz, J. L. C., \& Wendland, A. (2010). Environmental strarification in Paraná and Santa Catarina to evaluate common bean genotypes. Crop Breeding \& Applied Biotechnology, 10(2), 132-139. https://doi.org/10.12702/1984-7033.v10n02a05

Ramalho, M. A. R., Ferreira, D. F., \& Oliveira, A. C. (2012). Experimentação em genética e melhoramento de plantas. Lavras, MG-BR: UFLA.

Ribeiro, J. Z., \& Almeida, M. I. M. (2011). Environmental stratification by analysis of genotype $\times$ environment interaction in maize. Brazilian Journal of Agricultural Research, 46(8), 875-883. https://doi.org/10.1590/ S0100-204X2011000800013

Robertson, A. (1959). Experimental design on the measurement of heritabilities and genetic correlations: Biometrical genetics. New York, NY: Pergamon Press.

Rosa, T. C., Carvalho, I. R., Szareski, V. J., Pelegrin, A. J., ... Souza, V. Q. (2018). Agronomic Performance and Multivariate Analysis Applied to Three-Waycross Maize. Journal of Agricultural Science, 10, $319-328$. https://doi.org/10.5539/jas.v10n5p319

Scapim, C. A., Carvalho, C. G. P., \& Cruz, C. D. (1995). A proposal of variation coefficient classification for corn growing. Pesquisa Agropecuária Brasileira, 30(5), 683-686. Retrieved from http://www.alice.cnptia. embrapa.br/bitstream/doc/995743/1/Umapropostadeclassificacaodoscoeficientesdevariacaoparaaculturadom ilho.pdf

Silva, H. D., Pinto, R. D. M. C., \& Biase, N. G. (2004). A methodology for grouping of environments in order to minimize the genotypes $x$ enviornments interactions in maize hybrids evaluation. Bioscience Journal, 20(3), 61-67. Retrieved from http://www.seer.ufu.br/index.php/biosciencejournal/article/viewFile/6542/4276

Silva, J. R., Sousa Nunes, G. H., Negreiros, M. Z., Torres, J. F., \& Dantas, M. S. M. (2008). Genotypic $\times$ Environment Interaction in Watermelon in the Rio Grande Do Norte State. Revista Caatinga, 21(1), 95-100. Retrieved from http://periodicos.ufersa.edu.br/revistas/index.php/sistema/article/view/615/262

Szareski, V. J., Carvalho, I. R., Kehl, K., Levien, A. M., Nardino, M., Demari, G., ... Aumonde, T. Z. (2017). Univariate, multivariate techniques and mixed models applied to the adaptability and stability of wheat in the Rio Grande do Sul State. Genetics and Molecular Research, 16(3), 1-13. https://doi.org/10.4238/ gmr16039735

Szareski, V. J., Carvalho, I. R., Kelh, K., Pelegrin, A. J., Nardino, M., Demari, G. H., ... Souza, V. Q. (2018). Interrelations of Characters and Multivariate Analysis in Corn. Journal of Agricultural Science, 10(2), 187-194. https://doi.org/10.5539/jas.v10n2p187

Szareski, V. J., Carvalho, I. R., Nardino, M., Demari, G. H., Bahry, C. A., Kehl, K., ... Aumonde, T. Z. (2016). Phenotype stability of soybean genotypes for characters related to the physiological quality of seeds produced under different environmentall conditions. Australian Journal of Basic and Applied Sciences, $10(15), 279-289$.

Uitzil, A. M. P., Souza, V. Q., Olivoto, T., Nardino, M., Carvalho, I. R., Ferrari, M., ... Demari, G. (2016). Yield components of hybrid based on the plant population and artificial defoliation. Australian Journal of Basic and Applied Sciences, 10(10), 136-142. 
Zimmer, G., Zimmer, P. D., Koch, F., Szareski, V. J., Demari, G. H., Carvalho, I. R., ... Pedo, T. (2017). Effect of nitrogen application at sowing on plysiological quality of maize seeds. Australian Journal of Basic and Applied Sciences, 11(1), 73-77.

\section{Copyrights}

Copyright for this article is retained by the author (s), with first publication rights granted to the journal.

This is an open-access article distributed under the terms and conditions of the Creative Commons Attribution license (http://creativecommons.org/licenses/by/4.0/). 